JURNAL ILMU KESEHATAN BHAKTI HUSADA:

HEALTH SCIENCE JOURNAL, VOL. 12 NO. 01 , JUNI 2021

DOI: $10.34305 /$ jikbh.v12i1.260
Ciptaan disebarluaskan di bawah

Lisensi Creative Commons Atribusi-

NonKomersial-BerbagiSerupa 4.0

Internasional.

\title{
HUBUNGAN CARA PEMBERIAN ASI DENGAN KEJADIAN MASALAH PADA PUTING LECET DI UPTD PUSKESMAS NUSAHERANG
}

\author{
Nurdewi Sulymbona, Russiska, Mala Tri Marliana, Epa Sopiatul Mutaharoh \\ STIKes Kuningan \\ nurdewi63@gmail.com
}

\begin{abstract}
Abstrak
Ibu menyusui sering mengalami masalah puting susu lecet, dimana bayi hanya menyusu pada puting, sehingga bayi akan mendapatkan ASI sedikit karena gusi pada bayi tidak menekan sinus laktiferus. Hal ini menyebabkan puting ibu terasa nyeri atau lecet. Dampak dari puting lecet ini bukan hanya bagi ibu akan tetapi bagi bayi juga sehingga bayi tidak mendapatkan ASI penuh dari ibunya. Sering terjadi masalah sekitar 57\% dalam menyusui adalah masalah puting susu lecet.

Metode penelitian ini menggunakan analitik dengan rancangan cross sectional, populasi dalam penelitian ini ibu menyusui pada bulan Mei 2019. Teknik pengambilan sampel Total Sampling, dengan jumlah 60 orang instrument menggunakan lembar ceklis, analisis menggunakan univariat dan bivariat.

Berdasarkan hasil penelitian univariat menunjukkan ibu yang memberikan ASI secara langsung 40,\%, yang memberikan ASI Perah 60\%, dan yang mengalami puting lecet 43,3\%. Hasil analisis bivariat menunjukkan nilai $\mathrm{p}=0,019(<0,05)$.

Kesimpulan terdapatnya hubungan antara teknik menyusui dengan kejadian puting susu lecet pada ibu menyusui. Saran bagi ibu untuk meningkatkan pengetahuan tentang teknik menyusui yang benar dan dapat mengaplikasikannya dalam kehidupan sehari-hari, sehingga dapat meminimalisir terjadinya puting susu lecet.
\end{abstract}

Kata Kunci : Cara Pemberian ASI, Puting Susu Lecet 
JURNAL ILMU KESEHATAN BHAKTI HUSADA:

HEALTH SCIENCE JOURNAL, VOL. 12 NO. 01 , JUNI 2021

DOI: $\underline{10.34305 / \mathrm{jikbh} . v 12 \mathrm{i} 1.260}$
Ciptaan disebarluaskan di bawah

Lisensi Creative Commons Atribusi-

NonKomersial-BerbagiSerupa 4.0

\section{Pendahuluan}

Menurut (Nurjanah, SN, Maemunah, SA, Badriah, 2013) Air Susu Ibu (ASI) adalah makanan terbaik untuk bayi karena mengandung nutrisi yang seimbang dan sempurna untuk bayi. ASI mengandung nutrisi yang sangat baik untuk bayi sehingga jarang terjadi masalah pada kesehatan bayi.

Pemberian ASI memiliki banyak manfaat bagi ibu dan bayi. Beberapa manfaat ASI bagi bayi yaitu sebagai perlindungan terhadap infeksi gastrointestinal, menurunkan risiko kematian bayi akibat diare dan infeksi, sumber energi dan nutrisi bagi anak usia 6 sampai 23 bulan, serta mengurangi angka kematian di kalangan anak-anak yang kekurangan gizi, sedangkan manfaat pemberian ASI bagi ibu yaitu mengurangi risiko kanker ovarium dan payudara, membantu kelancaran produksi ASI, sebagai metode alami pencegahan kehamilan dalam enam bulan pertama setelah kelahiran, dan membantu mengurangi berat badan lebih dengan cepat setelah kehamilan (WHO UNICEF, 2016)

World Health Organization (WHO UNICEF, 2016) dan United Nations Children's Fund (UNICEF) tahun 2015, merekomendasikan agar ibu menyusui bayinya saat satu jam pertama setelah melahirkan dan melanjutkan hingga usia 6 bulan pertama kehidupan bayi. Pengenalan makanan pelengkap dengan nutrisi yang memadai dan aman diberikan saat bayi memasuki usia 6 bulan dengan terus menyusui sampai 2 tahun. Seorang ibu sering mengalami masalah dalam pemberian ASI eksklusif, salah satu kendala yaitu produksi ASI yang tidak lancar. Hal ini akan menjadi faktor penyebab rendahnya cakupan pemberian ASI eksklusif kepada bayi baru lahir (Wulandari SR, 2011).

Menurut kementrian RI 2013, cakupan pemberian Air Susu Ibu (ASI) di Indonesia pada tahun 2016 hanya 29,5\%, dan pada tahun 2017 menjadi 35,7\%, di Jawa Barat tahun 2016 jumlah cakupan ASI eksklusif mencapai 32,9\% sementara pemerintah mencanangkan cakupan ASI 0-6 bulan mencapai $80 \%$ pada tahun 2017 (Profil Data Kesehatan Indonesia, 2018)

Berdasarkan data yang diperoleh dari Kabupaten Kuningan yang menggunakan ASI eksklusif pada bulan Agustus tahun 2017 sebanyak 7.003 atau sebesar $71.00 \%$ dari jumlah total bayi.

Masalah yang sering terjadi dalam menyusui adalah puting susu lecet. Ibu yang menyusui sekitar 57\% dilaporkan pernah mengalami lecet pada putingnya. Kebanyakan puting lecet disebabkan oleh 
JURNAL ILMU KESEHATAN BHAKTI HUSADA:

HEALTH SCIENCE JOURNAL, VOL. 12 NO. 01 , JUNI 2021

DOI: $\underline{10.34305 / \text { jikbh.v12i1.260 }}$
Ciptaan disebarluaskan di bawah

Lisensi Creative Commons Atribusi-

NonKomersial-BerbagiSerupa 4.0 kesalahan dalam teknik menyusui yaitu bayi tidak menyusu sampai ke kalang payudara (Rinata, E, Rusdyati T, 2015).

Cara mengatasi hal itu dapat dilakukan dengan pemberian ASI perah kepada bayi, agar kebutuhan nutrisi kepada bayi dapat terpenuhi. (Yulitama, 2013) menjelaskan beberapa cara teknik memerah ASI salah satunya menggunakan jari tangan. Cara ini sangatlah sederhana dan tidak membutuhkan biaya, tempatkan tangan di salah satu payudara tepatnya di aerola, kemudian ibu jari dan telunjuk ditekan secara bersamaan, jika ASI sudah keluar masukkan ASI ke dalam botol

Seorang ibu perlu bahkan wajib untuk mendapat dukungan tentang cara menyusui yang benar. Keberhasilan menyusui dapat dipengaruhi dalam meletakan bayi pada payudara ketika menyusui. Bidan, dokter serta petugas kesehatan lainnya dapat membantu untuk mengatur posisi menyusui yang benar atau dengan mendemonstrasikan teknik menyusui (RY, 2015).

Berdasarkan studi pendahuluan yang telah dilakukan peneliti pada bulan juli selama 4 hari di UPTD Puskesmas Nusaherang Tahun 2019 didapatkan 10 ibu menyusui yang mengalami masalah puting lecet sebanyak 7 responden $(70 \%)$.

\section{Metode}

Penelitian yang digunakan yaitu jenis penelitian analitik dengan pendekatan cross-sectional yaitu variabel bebas dan variabel terikat diukur pada saat yang sama (Badriah, 2012).

Rancangan penelitian adalah komparasi yang tujuannya untuk menemukan ada tidaknya suatu hubungan antara variabel-variabel yang diteliti, dan jika ada hubungan maka akan diketahui seberapa eratnya hubungan atau berartinya hubungan tersebut (Dahlan, 2010).

Menurut (Badriah, 2012), populasi adalah kelompok subjek yang hendak dikenai generalisasi hasil penelitian. Sebagai suatu populasi, kelompok subjek tersebut harus memiliki ciri - ciri atau karakteristik bersama yang membedakannya dari kelompok subjek yang lain.

Dalam penelitian ini yang dijadikan populasi adalah seluruh ibu menyusui pada bulan Mei di UPTD Puskesmas Nusaherang Tahun 2019 sebanyak 60 orang.

Teknik sampling merupakan teknik yang pengambilan sampelnya untuk menentukan sampel yang akan digunakan dalam penelitian terhadap berbagai teknik sampling yang digunakan (Sugiyono, 2016). Teknik pengambilan sampel dalam 
JURNAL ILMU KESEHATAN BHAKTI HUSADA:

HEALTH SCIENCE JOURNAL, VOL. 12 NO. 01 , JUNI 2021

DOI: $\underline{10.34305 / \mathrm{jikbh} . v 12 \mathrm{i} 1.260}$
Ciptaan disebarluaskan di bawah

Lisensi Creative Commons Atribusi-

NonKomersial-BerbagiSerupa 4.0 Internasional. penelitian ini adalah total sampel yaitu seluruh ibu menyusui sebanyak 60 orang.

Variabel bebas adalah variabel yang variasinya mempengaruhi

variabel lain (Badriah, 2012). Dalam penelitian yang menjadi variabel bebasnya adalah Cara Pemberian ASI pada ibu menyusui.

Variabel terikat adalah faktor faktor yang diamati dan diukur oleh peneliti. Penelitian ini yang menjadi variabel terikatnya adalah seluruh ibu menyusui pada bulan Mei.

Menurut (Badriah, 2012), instrument adalah alat pengumpulan data yang telah baku atau alat pengumpulan data yang memiliki standar validitas dan reliabilitas. Alat pengumpulan data yang digunakan dalam penelitian ini adalah lembar checklist yang dibuat oleh peneliti berdasarkan variabel yang telah ditentukan.

\section{Hasil}

Analisis Univariat

1. Gambaran Cara Pemberian ASI Ibu Menyusui di UPTD Puskesmas Nusaherang.

Tabel 5.1 Distribusi Frekuensi Cara Pemberian ASI Ibu Menyusui di UPTD Puskesmas Nusaherang

\begin{tabular}{cccc}
\hline No & Cara Pemberian ASI & Frekuensi (f) & Presentase (\%) \\
1. & Secara Langsung & 24 & 40,0 \\
2. & ASI Perah & 36 & 60,0 \\
& Jumlah & $\mathbf{6 0}$ & $\mathbf{1 0 0}$ \\
\hline
\end{tabular}

Sumber : Hasil Penelitian Tahun 2019

Berdasarkan tabel 5.1 di atas dapat diketahui bahwa dari 60 responden sebagian besar ibu menyusui dengan ASI perah sebanyak 36 orang $(60,0 \%)$.
2. Gambaran Putting Susu Lecet Ibu Menyusui di Wilayah Kerja UPTD Puskesmas Nusaherang.

Tabel 5.2 Distribusi Frekuensi Puting Lecet Ibu Menyusui di UPTD Puskesmas Nusaherang.

\begin{tabular}{cccc}
\hline No & Puting Susu & Frekuensi (f) & Presentase (\%) \\
1. & Puting Lecet & 26 & 43,3 \\
2. & Puting Tidak Lecet & 34 & 56,7 \\
\hline
\end{tabular}


JURNAL ILMU KESEHATAN BHAKTI HUSADA:

HEALTH SCIENCE JOURNAL, VOL. 12 NO. 01 , JUNI 2021

DOI: $\underline{10.34305 / \text { jikbh.v12i1.260 }}$
Ciptaan disebarluaskan di bawah

Lisensi Creative Commons Atribusi-

NonKomersial-BerbagiSerupa 4.0

\section{Jumlah}

60

100

Sumber : Hasil Penelitian Tahun 2019

Berdasarkan tabel 5.2 di atas dapat diketahui bahwa dari 60 responden sebagian besar ibu menyusui dengan puting tidak lecet sebanyak 34 orang $(56,7 \%)$.

\section{Analisis Bivariat}

1. Hubungan antara cara pemberian ASI dengan kejadian puting susu lecet pada ibu menyusui di UPTD Puskesmas Nusaherang dengan p-value.

Tabel 5.3 Hubungan antara cara pemberian ASI dengan kejadian puting susu lecet pada ibu menyusui di UPTD Puskesmas Nusaherang

\begin{tabular}{|c|c|c|c|c|c|c|c|}
\hline \multirow{3}{*}{$\begin{array}{c}\text { Cara } \\
\text { Pemberian ASI }\end{array}$} & \multicolumn{4}{|c|}{ Masalah Pada Puting } & \multirow{2}{*}{\multicolumn{2}{|c|}{ Total }} & \multirow{3}{*}{ p-value } \\
\hline & \multicolumn{2}{|c|}{ Ya } & \multicolumn{2}{|c|}{ Tidak } & & & \\
\hline & f & $\%$ & f & $\%$ & f & $\%$ & \\
\hline Secara Langsung & 6 & 25,0 & 18 & 75,0 & 24 & 100 & 010 \\
\hline ASI Perah & 20 & 55,6 & 16 & 44,4 & 36 & 100 & 0,019 \\
\hline
\end{tabular}

Sumber : Hasil Penelitian Tahun 2019

Berdasarkan tabel 5.3 diketahui bahwa dari 36 responden yang memberikan ASI perah sebagian besar memiliki puting lecet sebanyak 20 orang $(55,6 \%)$ sedangkan dari 24 responden yang memberikan ASI secara langsung sebagian besar memiliki puting tidak lecet sejumlah 18 orang $(75,0 \%)$.

Hasil uji Chi Square diperoleh nilai yang signifikan $\mathrm{P}$ yaitu 0,019 dengan tingkat kemaknaan $\alpha=0,05$ dapat disimpulkan adanya hubungan cara pemberian ASI terhadap masalah puting susu lecet pada ibu menyusui di UPTD Puskesmas Nusaherang Kabupaten Kuningan Tahun 2019.

\section{Pembahasan}

Analisis Univariat

Berdasarkan hasil penelitian mengenai cara pemberian ASI dan kejadian puting susu lecet pada ibu menyusui didapatkan hasil dari 60 ibu menyusui dapat diketahui bahwa ibu dengan cara pemberian ASI perah sebanyak 36 orang (60,0\%).

Hal ini sesuai dengan teori (Sinsin, 2009), bahwa pemberian ASI bukan hanya diberikan secara langsung tetapi bisa juga diberikan secara tidak langsung (ASI Perah) memerah ASI juga dapat dilakukan secara manual dan bantuan alat, akan tetapi mengeluarkan ASI perah secara manual lebih baik dibandingkan mengeluarkan ASI dengan bantuan alat, pompa mekanis 
JURNAL ILMU KESEHATAN BHAKTI HUSADA:

HEALTH SCIENCE JOURNAL, VOL. 12 NO. 01 , JUNI 2021

DOI: $\underline{10.34305 / \text { jikbh.v12i1.260 }}$
Ciptaan disebarluaskan di bawah

Lisensi Creative Commons Atribusi-

NonKomersial-BerbagiSerupa 4.0 biasanya menyebabkan ketidaknyamanan dan tidak efektif sementara memijat payudara dengan tangan lebih alami.

(Ramadani, M, Hadi, 2013), menjelaskan keberhasilan ASI Eksklusif untuk ibu bekerja juga dapat dilakukan salah satunya dengan diberikan ASI perah yang kemudian ASI disimpan kedalam freezer, yang terpenting ibu tetap memperhatikan makanan yang bergizi seimbang dan minum air putih untuk menjaga stamina. Tetap berfikir positif, rileks, hindari pikiran negatif dan stress yang mungkin dapat berpengaruh tidak baik pada kelancaran ASI.

ASI juga dapat membantu pengosongan alveoli mammae sehingga memberikan sinyal ke hipotalamus untuk meningkatkan sekresi prolaktin, ini juga dapat membantu bagi ibu menyusui yang mempunyai masalah puting salah satunya puting lecet (Novayelinda, 2012). Frekuensi memerah ASI yang sering dapat meningkatkan produksi ASI dan sebaliknya frekuensi pemerahan yang rendah menjadi penyebab kurangnya volume ASI.

Banyak ibu yang belum paham teknik memerah ASI terutama ASI perah dan menganggap bahwa memerah ASI hanya membantu pengosongan payudara saja, terutama saat bayi tidak mau lagi menyusu dan payudara ibu sudah penuh, ibu juga beranggapan meremas payudara dapat beresiko terjadinya puting susu lecet.

Berdasarkan hasil penelitian diperoleh jumlah ibu menyusui yang mengalami puting susu lecet sebanyak 26 orang (43,3\%). Menurut Ambarwati (2008), Puting susu lecet merupakan trauma pada puting susu saat menyusui, selain itu terjadi pula retak dan pembentukan celah-celah. Puting susu lecet merupakan fenomena yang tidak asing lagi bagi para ibu-ibu menyusui, para ibu selalu menganggapnya hal wajar apalagi bagi ibu yang baru pertama kali menyusui. Namun sebenarnya para ibu menyusui belum mengetahui dan memahami tentang kejadian tersebut. Hal ini menunjukkan bahwa pengetahuan ibu tentang penyebab dari puting lecet masing sangatlah kurang meskipun dari tahun ke tahun banyak sekali ibu yang mengalaminya. Tidak menutup kemungkinan bahwa ada sebagian ibu yang sebenarnya mengetahui penyebab dari puting susu lecet, namun pada kenyataanya ibu menyusui menyepelekan hal ini dan tidak ada upaya untuk menghindarinya.

Hal ini sepaham dengan teori dari oleh (Dewi, V, Sunarsih, 2011), bahwa selain karena posisi menyusui yang kurang tepat, puting susu lecet dapat disebabkan 
JURNAL ILMU KESEHATAN BHAKTI HUSADA:

HEALTH SCIENCE JOURNAL, VOL. 12 NO. 01 , JUNI 2021

DOI: $\underline{10.34305 / \text { jikbh.v12i1.260 }}$
Ciptaan disebarluaskan di bawah

Lisensi Creative Commons Atribusi-

NonKomersial-BerbagiSerupa 4.0 oleh beberapa hal seperti oral thrush (Candidates) atau Dermatitis, dermatitis adalah kondisi kulit yang mengalami peradangan, peradangan dapat dilihat dengan adanya ruam, kulit merah, yang dapat menimbulkan rasa gatal.

Menurut (Wulandari SR, 2011), penyembuhan puting susu bervariasi namun rata-rata hanya 1-2 hari saja, namun ada juga yang sampai berminggu-minggu. Ibu yang masa penyembuhannya sampai berminggu-minggu adalah ibu dengan puting lecet hingga mengeluarkan nanah, Memang tidak hanya luka atau kemerahan, seperti pendapat bahwa umumnya menyusui akan menyakitkan dan kadangkadang akan mengeluarkan darah. Rata-rata ibu memilih untuk tetap menyusukan payudaranya dengan puting yang lecet, namun ada juga ibu yang enggan lagi menyusui bayinya. karena takut sakit. Namun mereka tidak mengoleskan air susu ke area puting yang lecet. ibu yang pernah mengalami puting susu lecet belum mengetahui cara mengatasi putingnya ketika lecet, bahkan ada yang tidak mau lagi menyusui bayinya karena takut sakit.

\section{Analisis Bivariat}

Berdasarkan uji statistik didapatkan bahwa terdapat hubungan antara teknik menyusui dengan kejadian puting susu lecet di UPTD Puskesmas Nusaherang dengan P-value 0.019. Menurut (Kristiyanasari, 2011), Masalah yang sering terjadi pada ibu menyusui salah satunya adalah puting lecet, menyusui yang benar adalah ketika sebagian besar areola tidak tampak, bayi menghisap dalam dan perlahan, bayi puas dan tenang ketika akhir menyusu. Akan tetapi kebanyakan bayi tidak menyusu sampai ke areola dan kebanyakan puting susu lecet disebabkan oleh iritasi dari bahan kimia, misalnya sabun, infeksi jamur dan bakteri.

Kendala pemberian ASI perah banyak informasi mengalami puting susu lecet, juga menyebabkan ASI keluar sedikit. Resiko memerah ASI salah satunya juga dapat menyebabkan luka pada puting susu sehingga pemberian ASI secara langsung di nilai lebih nyaman.

Sejalan juga dengan hasil penelitian (Yulitama, 2013), yang berasumsi bahwa perlekatan alat pumping yang salah dapat menyebabkan kejadian puting lecet, apabila posisi dan perlekatan tidak benar akan membuat puting mendapatkan tekanan dan penarikan yang lebih keras dari normalnya. Dan apabila ini terjadi akan menyebabkan puting ibu menjadi lecet. 
JURNAL ILMU KESEHATAN BHAKTI HUSADA:

HEALTH SCIENCE JOURNAL, VOL. 12 NO. 01 , JUNI 2021

DOI: $\underline{10.34305 / \text { jikbh.v12i1.260 }}$
Ciptaan disebarluaskan di bawah

Lisensi Creative Commons Atribusi-

NonKomersial-BerbagiSerupa 4.0
Hak tersebut sejalan juga dengan penelitian yang dilakukan oleh Erna dan Andi, (2017) di RSIA Sitti Khadijah 1 Kota Makassar yang pada penelitiannya bahwa dari 42 responden, berdasarkan teknik menyusui yang salah dan mengalami puting susu lecet adalah sebesar $14(60,9 \%)$ dan tidak lecet sebesar $9(39,1 \%)$, sementara berdasarkan teknik menyusui yang benar dan mengalami puting susu lecet adalah 2 (10,5\%) dan tidak lecet sebesar 17 (89,5\%). Hasil analisis yang dilakukan oleh penelitiannya adalah menggunakan uji ChiSquare dengan nilai $\mathrm{p}$-value 0,001 maka terdapat pengaruh teknik menyusui terhadap masalah puting lecet.

Pada saat dilakukan penelitian, peneliti mengamati bahwa kejadian puting susu lecet akibat pumping ASI salah satunya karena teknik memerah ASI yang salah, dimana ketika memerah masih banyak ibu yang belum paham bagaimana cara menjaga dan mensterilkan alat pumping ASI. Ada pula ibu menyusui yang menggunakan alat perah tanpa karet, sehingga pada saat memerah ASI itu yang menyebabkan terjadinya puting susu lecet. Semua ibu menyusui harus diberi arahan tentang praktek cara memerah ASI yang baik dan benar. Ini Sangat perlu dipelajari oleh setiap ibu menyusui karena memerah
ASI itu bukan suatu hal yang reflektif atau instingtif, tetapi merupakan suatu proses. Proses belajar yang baik bukan hanya untuk ibu yang pertama kali tetapi untuk semua ibu menyusui.

\section{Kesimpulan}

Berdasarkan penelitian yang telah dilakukan. Maka dapat disimpulkan sebagai berikut :

1. Cara pemberian ASI pada ibu menyusui di UPTD Puskesmas Nusaherang Tahun 2019 sebagian besar termasuk dalam kategori ASI perah sebanyak 36 orang $60,0 \%$

2. Kejadian puting susu lecet pada ibu menyusui di UPTD Puskesmas Nusaherang Tahun 2019 sebagian besar termasuk kategori puting susu tidak lecet yaitu sebanyak 26 orang $43,3 \%$.

3. Terdapat hubungan yang signifikan antara teknik menyusui dengan kejadian puting susu lecet pada ibu menyusui di UPTD Puskesmas Nusaherang, nilai $0,019 \mathrm{p}$-value $<0.05$.

\section{Saran}

Berdasarkan hasil penelitian yang telah dilakukan, diperoleh suatu kesimpulan sebagai berikut: 
JURNAL ILMU KESEHATAN BHAKTI HUSADA:

HEALTH SCIENCE JOURNAL, VOL. 12 NO. 01 , JUNI 2021

DOI: $\underline{10.34305 / \mathrm{jikbh} . v 12 \mathrm{i} 1.260}$
Ciptaan disebarluaskan di bawah

Lisensi Creative Commons Atribusi-

NonKomersial-BerbagiSerupa 4.0 Internasional
1. Bagi Ibu Menyusui diharapkan kepada ibu menyusui untuk dapat meningkatkan pengetahuan tentang teknik menyusui yang benar serta dapat melakukannya dan mengaplikasikannya dalam kehidupan sehari-hari. Ibu bisa melakukannya dengan cara membuka buku KIA, bertanya kepada bidan atau dengan searching di internet, sehingga dapat meminimalisir terjadinya puting susu lecet.

2. Bagi Bidan diharapkan hasil penelitian ini dapat dijadikan sebagai bahan masukan bagi bidan desa dalam rangka KIE pada ibu menyusui dengan cara memberikan penyuluhan maupun pendidikan kesehatan tentang teknik menyusui yang benar salah satunya teknik memerah ASI yang benar, sebagai upaya mencegah terjadinya puting susu lecet.

\section{Daftar Pustaka}

Badriah, D. . (2012). Metodologi Peneitian Ilmu - Ilmu Kesehatan. Multazam.

Dahlan, M. . (2010). Besar Sampel dan Cara Pengambilan Sampel dalam Penelitian Kedokteran dan Kesehatan. Salemba Medika.

Dewi, V, Sunarsih, T. (2011). Asuhan Kebidanan Pada Ibu Nifas. Salemba Medika.
Kristiyanasari, W. (2011). Asuhan

Kebidanan Neonatus dan Anak. Nuha Medika.

Novayelinda, R. (2012). Hubungan Cara Pemberian ASI Untuk Ibu Pekerja di Wilayah Kerja Puskesmas Manyaran Kecamatan Semarang Barat. Jurnal Kesehan Dan Budaya.

Nurjanah, SN, Maemunah, SA, Badriah, D. (2013). Asuhan Kebidanan Post Partum dilengkapi Asuhan Kebidanan Post Sectio Caesarea. Refika Aditama.

Profil Data Kesehatan Indonesia. (2018). Cakupan Pemberian ASI Eksklusif 0-6 Bulan. Kementrian Kesehatan Republik Indonesia.

Ramadani, M, Hadi, E. N. (2013). Dukungan Suami dalam Pemberian ASI Eksklusif di Wilayah Kerja Puskesmas Air Tawar Kota Padang Sumatera Barat. Jurnal Kesehatan Masyarakat Nasional.

Rinata, E, Rusdyati T, S. P. (2015). Teknik Menyusui Posisi, Perlekatan dan Keefektifan Menghisap-Studi pada Ibu Menyusui di RSUD Sidoarjo. Prosiding Seminar Nasional \& Internasional.

RY, A. (2015). Asuhan Kebidanan Masa Nifas dan Menyusui. CV Trans Info Media.

Sinsin, I. (2009). Masa Kehamilan dan Persalinan. PT. Elex Media Komputindo.

Sugiyono. (2016). Metode Penelitian Pendidikan Pendekatan Kuantitatif, 
JURNAL ILMU KESEHATAN BHAKTI HUSADA:

HEALTH SCIENCE JOURNAL, VOL. 12 NO. 01 , JUNI 2021

DOI: $\underline{10.34305 / \mathrm{jikbh} . v 12 \mathrm{i} 1.260}$
Ciptaan disebarluaskan di bawah Lisensi Creative Commons AtribusiNonKomersial-BerbagiSerupa 4.0 Internasional.

Kualitatif, dan R\&D. Alfabeta.

WHO UNICEF. (2016). Pedoman ASI Eksklusif(Jakarta). BKKBN.

Wulandari SR. (2011). Asuhan Kebidanan Ibu Nifas. Gosyen Publishing.

Yulitama, N. (2013). Hubungan Teknik Menyusui dengan Terjadinya Lecet Putting Susu pada Ibu Nifas. Jurnal Kebidanan, Universitas Mayjen Sungkono Mojokerto. 